\title{
Pentingnya Pengetahuan Mengenai Anemia Remaja Putri di SMA N 1 Tanjung Jabung Barat
}

\author{
Arnati Wulansari $^{1}$, Siti Aminah ${ }^{2}$, Rahmadiani $^{3}$ \\ 1,2,3Program Studi S1 Ilmu Gizi, STIKes Baiturrahim Jambi \\ Email: arnatiwulansari@ rocketmail.com
}

Submitted : 03/05/2021

Accepted: 14/06/2021

Published: 28/06/2021

\begin{abstract}
The low khowledge of teenager girl at SMA N 1 Tanjung Jabung Barat was one of the reason for distribution of iron supplemented tablets from Dinas Kesehatan Tanjung Jabung Barat. In addition, knowledge about iron supplemented tablets is also very minimal. So it is not uncommon for many reason that iron supplemented tablets are not consumed and are not properly distributed.one of efforts to overcome this problem is counseling about anemia. This activity was carried out at SMA $N 1$ Tanjung Jabung Barat. The implementation of this activity is from September 2020 to February 2021. The target of this activity is teenager girl of SMA N 1 Tanjung Jabung Barat. The implementation method are in the form of counseling and discussion. The results obtained in this activity were the goal of understanding the material about anemia. It is recommended that the school be able to work together with Puskesmas and Dinas Kesehatan to provide health education regularly when carry out activities to provide iron supplement tablets in order to understand the importance of knowledge about anemia.
\end{abstract}

Keywords: anemia, knowledge, teenager

\begin{abstract}
Abstrak
Rendahnya pengetahuan remaja putri mengenai anemia di SMA N 1 Tanjung Jabung Barat menjadi salah satu alasan penyaluran tablet tambah darah dari Dinas Kesehatan. Selain itu, pengetahuan mengenai tablet tambah darah juga sangat minim. Sehingga tidak jarang banyak alasan tablet tambah darah tidak dikonsumsi dan tidak tersalurkan dengan baik. Salah satu upaya penanggulangan masalah ini adalah penyuluhan mengenai anemia. Kegiatan pengabdian kepada masyarakat ini dilaksanakan di SMA $\mathrm{N} 1$ Tanjung Jabung Barat Kabupaten Tanjung Jabung Barat. Pelaksanaan kegiatan ini pada bulan September 2020 sampai Februari 2021. Sasaran kegiatan ini adalah siswi SMA N 1 Tanjung Jabung Barat. Metode yang digunakan dalam pelaksanaan kegiatan ini adalah metode konseling dan diskusi. Hasil yang diperoleh pada kegiatan ini adalah sasaran memahami materi mengenai anemia. Disarankan kepada pihak sekolah untuk dapat bekerja sama dengan puskesmas dan Dinas Kesehatan setempat untuk memberikan edukasi secara rutin setiap melakukan kegiatan pemberian tablet tambah darah agar memahami pentingnya pengetahuan mengenai anemia.
\end{abstract}

Kata Kunci: pengetahuan, anemia, remaja putri

\section{PENDAHULUAN}

Prevalensi Anemia di Indonesia masih cukup tinggi $(>20 \%)$ dan prevalensi tertinggi dialami oleh wanita $(27,2 \%)$. Berdasarkan proporsi anemia pada kelompok umur 5-14 tahun sebesar 26,4\%, 15-24 tahun sebesar 18,4\% tahun 2013 (Kemenkes RI, 2013). Proporsi anemia pada kelompok umur 15-24 tahun meningkat sebesar 32\% tahun 2018. Sebanyak 60,45\% remaja putri di Provinsi Jambi mengalami Anemia. Hal ini bahwa permasalahan anemia pada remaja masih menjadi masalah kesehatan masyarakat.

Remaja putri merupakan kelompok rawan penderita anemia. Salah satu program yang direkomendasikan WHO sejak awal tahun 1970-an adalah suplementasi besi-folat dan sudah dilakukan di Indonesia. Namun demikian perkembangan penurunan prevalensi anemia dinilai sangat lambat, bahkan pada tahun 2018 meningkat. 
Kegiatan Pengabdian kepada Masyarakat di SMA N 1 Tanjung Jabung Barat dilatarbelakangi rendahnya pengetahuan remaja putri mengenai anemia. SMA N 1 Tanjung Jabung Barat merupakan salah satu sekolah sasaran dari Dinas Kesehatan dalam penyaluran tablet tambah darah. Dengan fasilitas yang cukup memadai tidak berarti apabila sumber daya manusianya masih memiliki kekurangan pengetahuan gizi dan kesehatan. Sehingga tidak jarang banyak alasan tablet tambah darah tidak dikonsumsi dan tidak tersalurkan dengan baik.

Berdasarkan analisis situasi, permasalahan di SMA N 1 Tanjung Jabung Barat adalah 1) belum optimalnya peran fasilitas kesehatan daerah dalam pembinaan masyarakat khususnya dalam pengawasan konsumsi Tablet Tambah Darah (TTD); 2) masih rendahnya pengetahuan gizi tentang anemia dan Tablet Tambah Darah (TTD) sebagai sasaran program suplementasi gizi; dan 3) masih rendahnya dukungan kesehatan bagi remaja putri.

\section{TARGET DAN LUARAN}

Target dalam kegiatan pengabdian kepada masyarakat ini adalah siswi SMA N 1 Tanjung Jabung Barat. Adapun luaran kegiatan pengabdian kepada masyarakat ini selain publikasi pada jurnal ilmiah yaitu Pemahaman siswi terhadap pentingnya pengetahuan mengenai anemia, khususnya pentingnya konsumsi tablet tambah darah. Untuk selanjutnya siswi dapat mengonsumsi tablet tambah darah dengan rutin dan teratur guna mencegah terjadinya anemia pada remaja putri.

\section{METODE PELAKSANAAN}

Kegiatan pengabdian kepada September 2020-Februari 2021 dengan sasaran siswi SMA sebanyak 20 orang. Metode yang digunakan dalam kegiatan ini adalah memberikan edukasi terkait dengan anemia dan pencegahannya pada remaja putri secara daring. Tujuan dari kegiatan ini adalah menyampaikan informasi mengenai pentingnya mengetahui definisi, tanda dan gejala, dan pencegahan anemia pada remaja putri. Tindak lanjut dari kegiatan ini adalah diharapkan bagi remaja putri dapat mengenal dan kemudian menerapkan langkah-langkah pencegahan anemia, salah satunya adalah dengan mengonsumsi tablet tambah darah. Harapan lainnya adalah remaja putri yang mendapat edukasi ini dapat menyebarkan informasi ini kepada remaja putri lainnya guna turut serta membantu pemerintah dalam mencegah dan menanggulangi masalah anemia remaja putri. Berikut tahapan kegiatan pengabdian kepada masyarakat meliputi :

Tahap persiapan

Pada tahap persiapan, hal yang dilakukan adalah survei awal untuk mengetahui masalah dan kemudian mengidentifikasi akar masalah. Untuk selanjutnya dapat dirumuskan solusi yang dapat dilakukan. Dalam menentukan solusi, disampaikan rencana kegiatan yang akan dilakukan dan kemudian mengurus perizinan untuk melakukan kegiatan pengabdian kepada masyarakat.

Tahap pelaksanaan

Untuk pelaksanaan, hal yang dilakukan adalah melakukan pretest dengan memberikan kuesioner yang berisi pertanyaan terkait dengan materi yang akan disampaikan. Kegiatan dilakukan secara daring menggunakan zoom meeting. Selanjutnya memberikan materi terkait definisi, tanda dan gejala, serta langkah pencegahan anemia. Hal terakhir yang dilakukan adalah monitoring dan evaluasi terhadap materi yang telah diberikan berupa kegiatan posttest dan evaluasi terkait kehadiran menggunakan google form.

\section{HASIL DAN PEMBAHASAN}

Kegiatan penyuluhan ini bertujuan untuk memberikan edukasi kepada remaja putri terkait pentingnya pengetahuan mengenai anemia. Materi yang disampaikan 
pada kegiatan pengabdian kepada masyarakat ini berupa materi terkait anemia dan pencegahannya. Kegiatan penyuluhan berlangsung selama kurang lebih 45 menit dan telah terlaksana dengan tertib dan lancar, walaupun dilakukan secara daring melalui zoom meeting. Kegiatan dilakukan dalam bentuk pemberian edukasi anemia melalui metode ceramah melalui video, PPT dan juga leaflet mengenai anemia. Pokok materi yang disampaikan adalah definisi anemia, penyebab anemia, tanda dan gejala anemia, dampak anemia, dan langkah pencegahan anemia pada remaja putri.

Pada pelaksanaannya semua sasaran yaitu remaja putri menghadiri kegiatan sampai selesai sehingga capaian sasaran dalam kegiatan penyuluhan ini sebesar $100 \%$. Kegiatan penyuluhan ini didampingi oleh guru kelas dan juga wakil kepala sekolah bidang akademik. Setelah kegiatan ini dilakukan, diharapkan sasaran dapat mengaplikasikan ilmu yang disampaikan kepada teman-teman remaja putri lainnya dan masyarakat pada umumnya yang belum mengetahui terkait pentingnya memiliki pemahaman terkait anemia.

Sebelum dilakukan kegiatan pemateri memperkenalkan diri dan menjelaskan sedikit tujuan dari kegiatan penyuluhan ini kemudian peserta diberikan soal pre-test untuk mengukur pengetahuan awal sebelum diberikan penyuluhan. Pretest dan posttest dikirimkan melalui whatsapp berupa link pre dan post test sebanyak 20 buah pertanyaan. Setelah dilakukan penyuluhan, sasaran kembali diberikan soal post-test untuk mengukur pengetahuan sasaran setelah diberikan penyuluhan. Kemudian saat pelaksanaan pemberian edukasi, sasaran kegiatan ini merespon dengan baik terlihat dari adanya interaksi ketika diberikan pertanyaan-pertanyaan langsung terkait materi anemia, serta sasaran antusias dalam memberikan pertanyaan kepada anggota penyuluhan walaupun tidak semua sasaran yang bersemangat mengikuti penyuluhan ini.

Kegiatan pengabdian pada masyarakat berjalan sesuai dengan rencana yang dibuat. Selain dari pemahaman peserta terhadap penyampaian materi yang diberikan oleh pemateri yang diketahui dari tingkat partisipasi berupa tanya jawab yang baik, pemahaman peserta dalam konsumsi tablet tambah darah sebagai langkah pencegahan anemia cukup baik. Hal ini diketahui dari hasil diskusi dan kegiatan konsumsi tablet tambah darah bersama secara langsung..

Tabel 1. Kategori Hasil Pretest dan Posttest

\begin{tabular}{ccccc}
\hline Kategori & \multicolumn{2}{c}{ Pre Test } & \multicolumn{2}{c}{ Post Test } \\
& N & \% & n & \% \\
\hline Kurang $\leq$ & 11 & 55 & 0 & 0 \\
80 & & & & \\
Baik $\geq 80$ & 9 & 45 & 20 & 100 \\
\hline
\end{tabular}

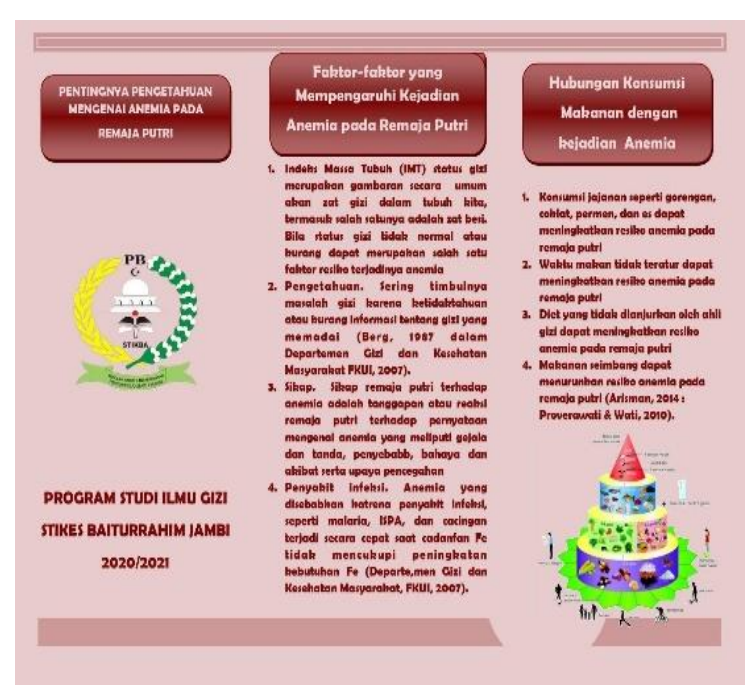

Gambar 1. Materi yang disampaikan

Berdasarkan Tabel 1, terjadi peningkatan pengetahuan siswi SMAN 1 Tanjung Jabung Barat setelah diberikan penyuluhan, dimana pada hasil pre-test didapatkan hasil hanya $45 \%$ pertanyaan yang dijawab dengan baik oleh siswi SMA sedangkan $55 \%$ pertanyaan lainnya tidak dapat dijawab dengan baik oleh siswi SMA, namun setelah diberikan penyuluhan dan 
diberikan post-test didapatkan hasil $100 \%$ pertanyaan dapat dijawab dengan baik oleh siswi SMA ini menunjukkan bahwa terdapat peningkatan hasil post-test setelah dilakukan penyuluhan. Hal ini sejalan dengan hasil penelitian yang dilakukan oleh Permatasari (2013) menunjukkan bahwa terjadi peningkatan pengetahuan responden dari sebelum dan setelah diberikan penyuluhan. Penelitian lain juga menunjukkan pengetahuan responden sebelum dan setelah penyuluhan mengalami peningkatan (Fadhilah, 2017).

Score terendah saat pre-test adalah 2 atau dapat dikatakan bahwa dari hasil pretest pertanyaan tersulit untuk dijawab oleh siswi adalah pertanyaa yang hanya dapat dijawab 2 dari 20 siswi yaitu pertanyaan kesebelas mengenai penyakit yang dapat menyebabkan anemia dan jawabannya adalah cacingan, karena cacing dapat menyerap zat gizi salah satunya zat besi dalam tubuh sehingga terjadi defisiensi zat besi dalam tubuh yang dapat meningkatkan resiko anemia, namun masih banyak siswi yang belum mengenai hal tersebut sehingga perlu peningkatan pengetahuan agar siswi lebih waspada dan menurunkan risiko anemia pada remaja putri.

Penyuluhan dilakukan dengan metode ceramah menggunakan bahasa yang mudah dimengerti oleh responden, materi penyuluhan diberikan dengan menggunakan power point sehingga responden tidak hanya mendengar tetapi juga melihat materi apa yang diberikan. Kegiatan penyuluhan berlangsung dengan kondusif sehingga informasi yang diberikan dapat maksimal diterima oleh responden. Hal ini menjadi salah satu faktor meningkatkanya pengetahuan dari sebelum dan sesudah penyuluhan. Penyuluhan bukan hanya digunakan sebagai metode untuk mempromosikan program-program kesehatan pemerintah. Penyuluhan dapat digunakan sebagai salah satu metode untuk menambah dan meningkatkan pengetahuan seseorang sehingga dengan bertambahnya atau meningkatnya pengetahuan seseorang dapat mengubah perilaku kesehatan dari yang tidak sehat menjadi sehat (Notoadmodjo, 2012).

Pentingnya pengetahuan mengenai anemia pada remaja putri dapat dilakukan sebagai langkah pencegahan terjadinya anemia pada remaja putri yang menjadi masalah kesehatan global (Junita dan Wulansari, 2021). Pemberian edukasi ini diharapkan memberikan dampak positif bagi remaja putri dalam mencegah anemia.

\section{KESIMPULAN DAN SARAN}

\section{Kesimpulan}

Pelaksanaan kegiatan pengabdian kepada masyarakat dengan sasaran remaja putri berjalan dengan baik. Sasaran dapat mengikuti kegiatan dari awal hingga akhir. Pada kegiatan ini juga terjadi peningkatan skor pengetahuan terkait pengetahuan anemia melalui penggunaan media PPT, video, dan leaflet.

\section{Saran}

Diharapkan kepada sasaran agar dapat rutin mengonsumsi tablet tambah darah dan juga menyebarkan informasi ini kepada remaja putri lainnya. Selain itu Disarankan kepada pihak sekolah untuk dapat bekerja sama dengan puskesmas dan Dinas Kesehatan setempat untuk memberikan edukasi secara rutin setiap melakukan kegiatan pemberian tablet tambah darah agar memahami pentingnya pengetahuan mengenai anemia. Hal ini diperlukan untuk mencegah dan menanggulangi masalah anemia.

\section{UCAPAN TERIMAKASIH}

Ucapan terima kasih penulis sampaikan kepada Sekolah Tinggi Ilmu Kesehatan Baiturrahim Jambi yang telah memfasilitasi kegiatan ini dan tak lupa kepada semua pihak yang telah membantu kegiatan pengabdian kepada masyarakat ini. 


\section{DAFTAR PUSTAKA}

Almatsier, Sunita. 2005. Prinsip Dasar Ilmu Gizi. Jakarta: Gramedia Pustaka Utama. Almatsier, Sunita. 2009.

Depkes RI. 2003. Indicator Indonesia Sehat 2020. Jakarta : Depkes RI

Dewoolkar, A, Patel, ND \& Dodich, C., 2014.Iron deficiency and Iron Deficiency Anemia in Adolescent Athletes: A Systematic Review.Int J Child Health Hum Dev . pp. 11-19

Fadhilah, D. 2017. Efektifitas Penyuluhan tentang Sayuran Menggunakan Media "Kartu Sayuran" terhadap Peningkatan Pengetahuan Siswa Sekolah Dasar. [Skripsi]. Yogyakarta: Poltekkes Kemenkes Yogyakarta.

Junita, D., Wulansari, A. 2021. Pendidikan Kesehatan tentang Anemia pada remaja putri di SMA N 12 Kabupaten Merangin. Jurnal Abdimas Kesehatan (JAK), 3 (1) : 42-46

Kementerian Kesehatan Republik Indonesia. 2014. Pedoman Gizi Seimbang 2014. Jakarta: Kementerian Kesehatan RI;

Kemenkes, RI. 2016. Buku Pedoman Pencegahan dan Penanggulangan Anemia Pada Remaja Putri dan Wanita Usia Subur (WUS). Jakarta: Direktorat Jenderal Kesehatan Masyarakat.

Kemenkes RI. 2018. Hasil Riset Kesehatan Dasar Provinsi Jambi. Jakarta : Kemenkes RI

Notoatmodjo, Soekidjo, 2007. Promosi Kesehatan dan Ilmu Perilaku. PT RINIKA CIPTA. Jakarta. 